\title{
SWOT Analysis on Industrial Development in Yongchuan District of Chongqing
}

\author{
Ping Ning ${ }^{a^{*}}$, Xin Liao ${ }^{\mathrm{b},}$ and Fei Ren ${ }^{\mathrm{c}}$ \\ Automotive engineering faculty, Chongqing creation vocational College, \\ Yongchuan, Chongqing, China \\ anp98783@163.com, b45785791@qq.com, '715707832@qq.com \\ ${ }^{*}$ Ping Ning
}

Keywords: Industrial development, SWOT, Analysis.

\begin{abstract}
Aiming at the demand of industrial development in Yongchuan district of Chongqing during the $13^{\text {th }}$ Five Year Plan period, applying SWOT analytical method, on the basis of the industrial development data of 2016, 2017 and 2018 in the district, the present situation of industrial development in Yongchuan district of Chongqing is discussed, the advantages, disadvantages, opportunities and threat from the industrial development existed in the locality are analyzed, then the proposal on industrial development in Yongchuan district is put forward.
\end{abstract}

\section{重庆市永川区产业发展的SWOT分析}

$$
\text { 宁萍 }{ }^{a}{ }^{*} \text {, 廖釒金 }{ }^{b} \text { 任飞 }{ }^{c}
$$

重庆科创职业学院 汽车工程系, 重庆永川, 中国

anp98783@163.com, b45785791@ qq.com, ${ }^{\mathrm{c}} 715707832 @ q q . c o m$

*宁萍

关键词：产业发展；SWOT；分析

中文摘要：针对重庆市永川区“十三五”规划期间产业发展的需求，运用SWOT分析法，以永 川区2016年～2018年产业发展数据为依据, 讨论了重庆市永川区产业发展的现状, 分析了当 地产业发展存在的优势、劣势、机会及威胁，并提出了永川区产业发展的建议。

1. 引言

当前，市场、产品、技术面临快速变化，变化中挑战和机遇并存。今年是新中国成立 70 周年, 是全面建成小康社会关键之年; 是产业结构转型升级、迈向高质量发展的机遇期, 是 创新创业的好时代; 加快产业结构升级、提升科技创新能力、推动经济高质量发展至关重要。

\section{2. 永川区产业发展现状}

永川区隶属于重庆市，位于重庆西部，介于成都、重庆两大城市之间；因“城区三河汇碧、 形如管文“永”字”而得名, 公元776年置县。解放初期, 永川县属巴县区行政专员公署, 隶属四 川省。1983年4月, 永川地区行政公署撤销并入重庆市, 永川县改隶重庆市。1992年5月, 永 
川撤县建市。2006年12月, 经国务院批准撤市设区 ${ }^{[1]}$, 永川区幅员面积1576 $\mathrm{kM}^{2}$ 。经过多年 的改革开放，目前永川区的产业结构逐渐趋于合理，并向优化和升级方向发展。

\subsection{6 年永川区产业结构}

2016 年, 是十三五开局之年, 永川区经济发展保持平稳较快增长。2016 年永川全区实现 生产总值 636.2 亿元, 同比增长 $11.6 \%$, 规上工业增加值增长 $11 \%$, 一般公共预算收入增长 $5.9 \%$, 社会消费品零售总额增长 $15.3 \%$; 重点产业集群快速扩张, 园区迈上千亿级台阶, 机 器人及智能装备等产业集聚发展, 成为国家新型工业化装备制造（机器人）示范基地。

2016 年，永川区三次产业结构占比为 8.7：56.0：35.3 $3^{[2]}$ 。

\subsection{7 年永川区产业结构}

2017 年，永川区主要经济指标平稳增长，经济结构优化、质量效益提升。2017 年，永川 区实现地区生产总值 704.5 亿元, 比 2016 年增长 9.4\%。其中第一产业实现增加值 57.1 亿元, 增长 $3.9 \%$; 第二产业实现增加值 397.7 亿元, 增长 $11.1 \%$, 第三产业实现增加值 249.7 亿元, 增长 $8.0 \%$ 。2017 年, 永川区实现工业增加值 390.4 亿元，同比增长 $10.9 \%{ }^{[3]}$ 。

2017 年永川区三次产业结构比由 2016 年的 8.7：56.0：35.3 调整为 8.1：56.5：35.4 ${ }^{[3]}$ 。

\subsection{8 年永川区产业结构}

2018 年, 永川全区实现地区生产总值 845.7 亿元, 增长 9.9\%; 第一产业增加值 62.2 亿元, 比上年增长 4.6\%; 第二产业增加值 425.2 亿元, 比上年增长 $9.6 \%$, 其中, 工业增加值 319.0 亿元，比上年增长 $8.4 \%$ ；第三产业增加值 358.3 亿元，比上年增长 $11.3 \%$ 。

2018 年全区固定资产投资比上年增长 $10.2 \%$ 。第一产业投资比上年增长 $15.3 \%$ ，第二产 业投资（全部为工业）比上年增长 $10.8 \%$ ，第三产业投资比上年增长 $9.5 \%$ 。

2018 年，永川区三次产业结构由 2017 年的 8.1：56.5：35.4 调整为 7.4：50.3：42.3 ${ }^{[4]}$ 。

\subsection{6～2018年永川区各产业占比}

永川区 2016 2018 年三类产业占比如表 1 所示。

\begin{tabular}{cccc}
\multicolumn{3}{c}{ 表1 } & 永川区2016 2018年三次产业占比 \\
\hline 年度 & $\begin{array}{c}\text { 第1产业 } \\
\text { 占比 }\end{array}$ & $\begin{array}{c}\text { 第2产业 } \\
\text { 占比 }\end{array}$ & $\begin{array}{c}\text { 第3产业 } \\
\text { 占比 }\end{array}$ \\
\hline 2016 & 9.4 & 57.5 & 33.1 \\
2017 & 8.1 & 56.5 & 35.4 \\
2018 & 7.4 & 50.3 & 42.3 \\
\hline
\end{tabular}

从表 1 不同产业占比可见, 2016 年以来, 永川区第一产业的比重从 9.4 降到 7.4, 降低了 2.0 个百分点; 第二产业比重从 57.5 降到 50.3, 降低了 7.2 个百分点; 第三产业比重从 33.1 上升到了 42.3 , 上升了 9.2 个百分点; 即永川区 2018 年第一、第二产业占比下降, 而第三产 业占比明显增长。

\section{3. 永川区产业发展的SWOT分析}

\section{1 优势分析}

\section{1 .1 党政高度重视}

中共重庆市永川区委、区政府对产业发展高度重视。永川区委、区政府全面落实党中央、 国务院、重庆市委一系列改革部署, 积极推进产业结构优化, 持续激发创新驱动内生动力, 深入落实“优化营商环境 22 条”、“营造企业家健康成长环境 30 条”，持续开展优化营商环境 整治，构建亲清新型政商关系，全力打造透明高效的政务环境，取得了显著的成效。 


\subsection{2 区位和便利的交通资源}

永川区位于长江上游、重庆西部，东邻江津区、壁山区，北界铜梁区，西接荣昌区、大 足区, 南与四川省合江县、沪县接壤, 是成渝城市群的节点城市、区域交通枢纽站, 东距重 庆市区 $55 \mathrm{kM}$ ，西离成都 $276 \mathrm{kM}$ 。已建和在建对外通道有“四高”（成渝高速公路、重庆西三环 高速公路、渝永高速公路、永泸高速公路）、“三铁”（成渝铁路、成渝高铁、渝昆高铁）、“一 港区”（永川港区）、“一机场（通用航空机场）”，交通便利。

永川区具备产业发展的区位优势、水文、交通、土地等资源 ${ }^{[1]}$ 。

\subsection{3 优惠的政策支持}

投资永川，享受西部大开发、长江经济带、成渝经济区、重庆自贸区、重庆市和永川区 招商引资等多重叠加优惠政策; 享受研发补贴、 10 元 $/ \mathrm{M}^{2}$ 的城市建设配套费、增值税专项补贴、 弹性地价、融资支持等多项政策支持 ${ }^{[1]}$ 。

\section{1 .4 重点领域改革加速}

深化“放管服”改革，推行审批服务“马上办、一次办、网上办、并联办、全程代办”，开 展工程建设项目审批制度改革试点，社会投资项目审批时限压减至50个工作日以内；全面实 施“多证合一”“证照分离”和全程电子化登记，承诺总时限比法定总时限缩短 $50 \%$ 。

\subsection{5 现有产业集群}

依托凤凰湖产业园、港桥产业园、三教产业园和软件园，培育发展高端数控机床等智能 装备、电子信息、汽车及零部件、特色轻工、能源及新材料、软件与信息技术服务六个主导 产业集群，加快建设全市重要的现代制造业基地，积极打造高质量发展先行区。

\section{2 劣势分析}

当前，永川仍处于欠发达阶段、属于欠发达地区，经济社会发展中还存在不少问题。

3.2.1 经济转型仍然困难

经济转型困难, 持续稳定增长的基础还不牢固, 发展韧性、创新能力有待进一步加强。

\section{2 .2 城乡发展不平衡}

城乡发展不平衡, 城乡基础设施、生态环保等存在不少欠账, 公共服务水平有待提高。

\subsection{3 财政资金使用绩效不高}

财政收支矛盾日益突出，债务管控压力加大，财政资金使用绩效有待进一步提升 ${ }^{[4]}$ 。

\subsection{4 作风建设仍需加强}

作风建设仍需加强, 少数干部法纪红线意识、廉政底线意识、服务发展意识仍需提高, 营商环境有待进一步优化等。

\section{3 机会分析}

将永川区与周边区县江津、璧山、铜梁、大足、荣昌、合江及沪县的产业集群布局进行 比较, 比较结果详见表 2 。

表2 永川区与周边区县产业集群布局比较表

\begin{tabular}{|c|c|c|c|c|c|c|}
\hline 地区 & \multicolumn{7}{|c|}{ 产业集群布局 } \\
\hline 江津 & -- & 汽车零部件 & 电子信息 & 装备制造 & 新型材料制造 & 食品加工 \\
\hline 璧山 & -- & 汽车零部件 & 信息技术 & 智能装备 & & \\
\hline 铜梁 & 轨道交通制造 & 汽车零部件 & 大健康产业 & 智能制造 & 新能源新材料 & 农产品加工 \\
\hline 大足 & 五金家居 & 汽摩零部件 & 新兴产业 & 高端装备 & -- & 文化旅游 \\
\hline 荣昌 & 轻工陶瓷 & --- & 兽药饲料 & 装备制造 & 环保建材 & 食品医药 \\
\hline 合江 & 酒类制造 & -- & 农副食品加工 & 化工、造纸 & 能源行业 & 食品制造 \\
\hline 沾县 & 酒类制造 & -- & 医药制造 & 化工 & 新材料产业 & \\
\hline 永川 & 软件与信息 & 汽车零部件 & 电子信息 & 智能装备 & 能源及新材料 & 特色轻工 \\
\hline 结果 & 具备差异性 & 不具差异性 & 具备差异性 & 不具差异性 & 不具差异性 & 具备差异性 \\
\hline
\end{tabular}


从表2分析得出如下观点:

一是永川区现有的软件与信息技术服务产业、电子信息产业、特色轻工产业与周边区县 相比较, 具有差异性。二是永川区现有的汽车及零部件产业、智能装备产业、能源及新材料 产业不具备差异性。

\section{4 威胁分析}

\subsection{1 现有产业间企业竞争所带来的威胁}

在当前的市场环境下，永川区现有的汽车及零部件产业、智能装备产业、能源及新材料 产业不具备差异性, 因此, 在发展这类产业时具有一定的风险和威胁。如汽车及零部件产业, 如果不具备区别于周边区县的汽车及零部件产业的特色, 则存在随时被周边区县汽车及零部 件产业吞并的威胁。

\section{4 .2 重庆市内区县间企业竞争所带来的压力}

当前，重庆市各级政府都把发展区域经济提到党政工作的第一位。因此，各地不断地抛 出政策引导、税收优惠、产业扶持等多种措施。各种优惠政策的出台, 使得竞争态势十分激 烈，在资金、人才、资源、市场等方面形成巨大的竞争压力。永川区产业发展面临着“不进则 退、小进慢进也是退”的严峻形势。

\section{SWOT分析建议}

据以上分析, 说明当前永川区的产业发展优劣势并存, 但机遇大于威胁。只要抓住机遇, 发挥自身优势, 补足短板, 寻求适合自身的发展道路, 就能实现良好发展 ${ }^{[5]}$ 。为此, 提出永 川区产业发展的建议: 采用差异化发展战略, 大力发展与周边区县的现有产业具有差异性的 产业, 如软件与信息技术服务产业、电子信息产业、特色轻工产业; 限制发展与周边区县具 有相似性、雷同性的产业，如智能装备及能源及新材料产业等。

\section{致谢}

本文为重庆市永川区2019年软科学计划项目《永川区汽车及零部件产业发展对策研究》 (Ycstc, 2019rb0701) 的阶段性成果之一。

\section{References}

[1] Yongchuan district people's government Official website in Chongqing municipality

[2] Qing-quan LUO, The government work report 2017 in Yonhchuan Chongqing Municipal People's Government [R] Yongchuan district government official website.2017.1.10

[3] Qing-quan LUO, The government work report 2018 in Yonhchuan Chongqing Municipal People's Government [R] Yonhchuan district government official website.2018.1.12

[4] Guo ZHANG, The government work report 2019 in Yonhchuan Chongqing Municipal People's Government [R] Yonhchuan district government official website.2019.1.16

[5] Xin GU, Jian-qiang, YANG, Research on the development strategy of big data industry in Gui Zhou based on SWOT analysis[J]. China Southern Agricultural Machinery pp. 32-33, 2019(15). 